\title{
A Cayman Islands Perspective on Transborder Insolvencies and Bankruptcies: The Case for Judicial Co-Operation
}

\author{
Anthony Smellie \\ Cayman Islands Judiciary, Grand Cayman, Cayman Islands \\ Email: cijudges@candw.ky \\ Received August $4^{\text {th }}$, 2011; revised September $10^{\text {en }}, 2011$; accepted October $6^{\text {th }}, 2011$.
}

\begin{abstract}
The freedom of movement of capital in the modern global economy has been indispensable to the development of international corporate enterprise. This paper argues that the judicial and legal institutions of states are as essential to the stability of the global economy as the traditionally heralded international economic channels that have been so carefully crafted globally. In fact, in the sphere of trans-border insolvency and bankruptcy, judicial and legal institutions could be perceived as even more vital, as the vibrancy and the health of global enterprises can be radically challenged and even severely impeded should countries fail to institute universally accepted legislative and judicial codes of practices. The quest for this normative approach has found expression by the United Nations in its development of the UNCITRAL Model Law, a prototype which has since been adopted by twenty-two States. A number of other States, as well, have adopted measures which mirror the cooperation and co-ordination principles of the UNCITRAL Model Law These States all accept that legislative and judicial capacity and competence are essential ingredients in the salutary infusion of mutual confidence, and it is this very shared trust that is the ultimate catalyst for successful resolution of cross-border and other disputes. For Offshore Financial Centres (OFCs), reinforcement of confidence in their Courts in the international arena is perhaps even more highly critical to their sustained roles in today's globalized economy. This paper outlines the legislative and judicial competencies and roles that have enabled the Cayman Islands, as an example of a key OFC, to emerge as a major player in international cross-border conflict resolution. This discourse also acknowledges the hurdles OFCs have had to overcome in both perceptions and reality in the global marketplace and the increased pressures faced by Courts today in meeting demands of public policy objectives. With specific regard to the Cayman Islands as an example of an effectively functioning OFC, the paper examines the Islands' insolvency regime, reviews a number of cases demonstrating the efficacy of the approach of the Islands' Courts, and highlights relevant Cayman Islands' legislation and orders made pursuant to those laws. This analysis demonstrates how, by implementing through its Courts a public policy model on a par with international codes of conduct, the territory has vouchsafed its ability to render the kind of international judicial assistance that is critical to the fulfilment of the tenets of the UNCITRAL Model law and to the principles of universality of bankruptcy that the Law embraces. A further benefit is that Cayman's Courts and court-appointed officials, in turn, may expect to receive full cooperation from other jurisdictions. Indeed, the emergence of the Cayman Islands as a leader among financial centres is due in no small part to its compliance with international regulatory requirements across the breadth of its financial industry. In addition to complying with FATF Directives on money laundering, the territory complies with OECD threshold requirements for tax information exchange and serves as a member of the Steering Committee of the OECD's Global Forum on Transparency and Exchange of Information. Furthering its position of strength, the Islands' legal and judicial system is based on English common law traditions, and its local legislative arsenal is being constantly modernized to meet contemporary Cayman Islands' needs. This legislative progression, given the Islands' continued status as a British Overseas Territory (UKOT) located in the North West Caribbean Sea, includes the extension, as required, of United Kingdom legislative provisions to the Islands.
\end{abstract}

Keywords: Global Economy; Bankruptcy; Judicial Capacity; Cross-Border; Insolvency Regime; Legislation 


\section{Introduction}

Since World War II, economists, business interests and politicians have worked together to promote trade and growth and manage adverse consequences. Institutions such as the World Bank, the International Monetary Fund and the World Trade Organisation were formed as vehicles for global objectives. Barriers to international trade have been lowered through international agreements, such as the General Agreement on Tariffs and Trade (GATT).

This structure has fostered the emergence of worldwide production markets and allowed consumers and corporations broader access to worldwide markets and foreign products. It was intended to, and has successfully stimulated the emergence of, worldwide financial markets and created easier access to external financing for corporate and governmental borrowers alike.

As a central tenet of this post-World War II phenomenon, "freedom of movement of capital" has been the clarion call. So much so that it has found expression at the core of the most advanced political economic unions. For instance, Article $73 \mathrm{~b}(1)$ of the European Community Treaty provides in terms that within the framework of the other provisions of the Treaty "all restrictions on the movement of capital between Member States and between Member States and Third countries shall be prohibited".

Because of the size and strength of its economy and the influence of the dollar, the United States has been very successful in utilizing the global market place. Like the United States, the rapid rise of the Chinese economy, the growth of India's economy, and the success of the European Union are all due to the ability of their economies to respond to the opportunities provided by globalization.

Other emerging economies also recognise the benefits to be gained from globalization, and the competition amongst them to attract inward investment has become a driving force of the international financial markets.

This is the well-spring of international financial activity from which the Offshore Financial Centres (“OFCs”)

\footnotetext{
${ }^{1}$ This is a provision that the European Court has been called upon to interpret in a number of cases [C-484/93; C-367/98; C-483/99; C503/99; C-174/04].

In Case C-367/98-Commission of European Convention v Portuguese Republic, the Court emphasized the particular importance of the freedom of investors to acquire shares in corporate entities, including where such entities may own and control national undertakings. In this regard, the Court held that: "A member state which adopts and maintains in force national rules 1) prohibiting the acquisition by investors from other Member States of more than a given number of shares in certain national undertakings and 2) requiring the grant by the State of prior authorisation for the acquisition of a holding in certain national undertakings in excess of a specified level fails to comply with its obligations under Article $73 b$ of the Treaty (now Article 56 EC)."
}

have emerged.

That activity also explains the advent of offshore corporate vehicles and gives the background to their important role as instruments for the movement of capital in the global economy.

In this context, the success of some of the OFCs demonstrates that the only way that they can and will survive as global players in international financial markets is to ensure that their legal and judicial institutions comply fully with common law principles of comity, in line with the principles of the UNCITRAL Model Law.

\section{Historical Misconceptions about OFCs}

The role of OFCs and of offshore corporate vehicles has been a constant source of controversy. This paper does not proceed on a premise that is oblivious to the perennial debate about this subject, generated especially by the concerns about "harmful tax competition" and about the unfavourable impact some OFCs could potentially have upon the high tax regimes of "Onshore” jurisdictions. ${ }^{2}$

But such concerns having been time and again met and addressed by the OFCs within the various international fora, the debate should not be allowed to detract from the reality of the crucial role of offshore companies, the recognition of which is necessary for a proper appreciation of the juridical and economic imperatives that require the giving of judicial co-operation, not only by the judiciary of the OFCs to the judiciary of Onshore jurisdictions, but also the other way around. ${ }^{3}$

\section{Courts' Cooperation and Co-Ordination- the Challenges}

Indeed, the recent global financial crisis and the consequential failure of many transnational entities have challenged the courts of countries-including the OFCs-to respond with unprecedented urgency and efficacy. The nature of the challenge has come to be described in the

\footnotetext{
${ }^{2}$ The impact that OFCs have upon the global financial system is now regarded in a more positive light by "Onshore" regulators, since the OFCs' near universal acceptance of the need for strict anti-money laundering regimes and tax co-operation agreements. The Cayman Islands complies with FATF Directives on money laundering and with OECD threshold requirements for tax information exchange agreements and serves as a member of the Steering Group of the OECD's Global Forum on Transparency and Exchange of Information. As long ago as 5th April 2000, the Financial Stability Forum of the IMF concluded that the OFCs present no threat to world financial stability. See its Report of that date at page 9 Box 3 where some of the benefits of OFCs are discussed. www.financialstabilityboard.org/publication.

${ }^{3}$ There is already a body of academic work in support of the proposition that OFCs are beneficial in the impact that they have on the global economy. See for instance: "Offshore Financial Centers and Regulatory Competition" Edited by Andrew P. Morriss; AEI Press. (May 2010) and "Offshore Financial Centers and the Canadian Economy" by Walid Hijazi, Rotman School of Management, University of Toronto.
} 
"co-operation" and “co-ordination" principles of the UNCITRAL Model Law on Cross-Border Insolvency, Articles 25, 26, 27, 29 and 30. These provisions place obligations on both courts and insolvency representatives in different States to communicate and co-operate to the maximum extent possible, to ensure that a debtor entity's insolvent estate is administered fairly and efficiently, with a view to maximizing benefits to creditors. Those principles are designed to meet the following public policy objectives:

1) The need for greater legal certainty for trade and investment;

2) The need for fair and efficient management of international insolvency proceedings, in the interests of all creditors and other interested persons, including the debtor;

3) Protection and maximization of the value of the debtors' assets for distribution to creditors, whether by reorganization or liquidation;

4) The desirability and need for courts and other competent authorities to communicate and cooperate when dealing with insolvency proceedings in multiple states; and

5) The facilitation of the resumption of financially troubled businesses with the aim of protecting investment and preserving employment.

This is a far-reaching and daunting mandate. However, as a basic position from which to respond, it is reassuring that the commercial necessity for international co-operation between courts in matters of cross-border insolvency has long been recognized and is repeatedly stressed in case law. ${ }^{4}$

\section{The Cayman Islands’ Insolvency Model}

As in England and Wales, in the Cayman Islands foreign bankruptcy or insolvency proceedings (whether corporate or personal) may be recognized at common law if the bankrupt or debtor company submitted, or is properly deemed to have submitted, to the jurisdiction of the foreign court. See Barclays Bank plc v. Homan (1993) BCLC 680, In the Matter of Al-Sabah (below); and, in the case of foreign corporate receiverships, see the seminal Cayman Islands decision in Kilderkin v Player (below).

Judicial international co-operation is a well-established tradition in Cayman Islands' jurisprudence, and the common law conflict-of-law rules applicable in this area are carefully applied. The circumstances under which assistance may be given or requested and the principles

\footnotetext{
${ }^{4}$ See for example: In re African Farms Ltd. [1906] T.S. 373; Schemmer v Property Resources Ltd. [1975] Ch. 273; In Re Bank of Credit and Commercial S.A.. [1992] BCLC 570; Banque Indosuez v Ferromet Resources Inc. [1993] BCLC 112.
}

that guide the making or granting of requests are many and varied. Many instances are the subject of judicial pronouncement. The Cayman Islands Law Reports contain the reported judgments on the subject of judicial international assistance. ${ }^{5}$ Some of these judgments have come to attract academic interest in seminal textbooks on the subject. ${ }^{6}$

Comity as a Central Tenet of OFC Survival: The over-arching principle is, of course, Comity-that civilized notion that requires reciprocity of co-operation and assistance between the courts of different countries, classically described by Lord Denning in the Westinghouse case in relation to a request by the United States Federal Court in this way:

"It is our duty and pleasure to do all we can to assist that court, just as we would expect the United States Court to help us in like circumstances. Do unto others as you would be done by."7

An alternative and more categorical definition was given as long ago as 1895 by the United States Supreme Court in Hilton v Guyot (1895) 159 U.S. 113, 164, in the following terms recently adopted by the Cayman Islands Court of Appeal: ${ }^{8}$

"...comity is the recognition which one nation allows within its territory to the legislative, executive or judicial acts of another nation, having due regard to international duty and convenience, and to the rights of its own citizens or of other persons who are under the protection of its laws."

This established and increasing reliance on comity has come, in the field of bankruptcy and corporate insolvency, to embrace the principle of universality, explained by Lord Hoffmann in a trilogy of seminal judgments given on behalf of the House of Lords and the Privy Council. Perhaps most famously, in the following terms from the second judgment, that given in the Cambridge Gas case:

"The English common law has traditionally taken the view that fairness between creditors requires that, ideally, bankruptcy proceedings should have universal applica-

\footnotetext{
${ }^{5}$ See www.caymanjudicial-legalinfo.com.ky/judgments/index

${ }^{6}$ Cross-Border Judicial Co-operation in offshore litigation (The British Offshore World) Editors: Ian R. C. Kawaley, Andrew Bolton and Robin J. Major; Widdy Simmonds \& Hill publishing; Confidentiality in Offshore Financial Law; Prof. Rose-Marie Antoine; Oxford University Press.

${ }^{7}$ In Re Westinghouse Uranium Contract [1978] 1 AC 547,560.

${ }^{8}$ In HSH Cayman II GP Ltd. and others v ABN Amro Bank N.V. London, Civil Appeal No. 3 of 2010 (Judgment: 24 May 2010). In this case the Court of Appeal unsurprisingly did not accede to an application for a stay of a local petition to wind up HSH in deference to proceedings which were merely proposed to be brought in Delaware but not yet instituted there. It was proposed to place HSH in Chapter 11 Bankruptcy proceedings there. The local petition was found to be properly based upon a due but unpaid liability and no realistic prospect of a compromise by way of Chapter 11 proceedings was shown to exist.
} 
tion. There should be a single bankruptcy in which all creditors are entitled and required to prove. No one should have an advantage because he happens to live in a jurisdiction where more of the assets or fewer of the creditors are situated... universality of bankruptcy has long been an aspiration, if not always fully achieved, of United Kingdom law. And with increasing world trade and globalization, many other countries have come around to the same view."

“...the underlying principle of universality...is given effect by recognising the person who is empowered under the foreign bankruptcy law to act on behalf of the insolvent company (or bankrupt) as entitled to do so in England.",9

The cases also reflect the important developments at common law which now clearly recognise that "bankruptcy, whether personal or corporate, is a collective proceeding to enforce rights, not to establish them" (per Lord Hoffman in the Cambridge Gas case (para. 15)). The import of this statement, for present purposes, is that a foreign insolvency or bankruptcy proceeding may be granted recognition as a collective regime for the enforcement of rights, though particular stakeholders may seek to assert different rights and may not have submitted to the jurisdiction of the foreign courts, provided that their interests (as shareholder or creditor) are to be properly regarded as subsumed within the collective enforcement regime of the foreign proceedings. ${ }^{10}$

\section{A Review of Cayman Islands' Insolvency Cases}

A review of Cayman Islands cases will reveal that the aspirations embodied in the principle of universality and in the mandate in the case law for the collective enforcement of rights in insolvency and in bankruptcy have, for quite some time, been shared, recognized and enforced by the Courts.

Kilderkin v. Player 1984 CILR 63: This case, decided by the Cayman Court of Appeal, is an appropriate starting point. There a receiver, having been appointed as such over an Ontario-registered company by the Supreme Court of Ontario, applied to the Cayman Grand Court for an order recognizing its appointment. The receiver had been appointed at the instance of investors and creditors whose investments had been diverted to purposes outside the authorised scope of investments by the principals of

${ }^{9}$ Cambridge Gas Transportation Corp. v Official Committee of Unsecured Creditors of Navigator Holdings plc and others [2007] 1 AC 508 at 517 to 518. See also Wight v Eckhardt Marine GmbH 2003 CILR 211 (P.C. on appeal from the Cayman Islands and In Re HIH Casualty and General Insurance Ltd. [2008] 1 WLR 852 H.L., and see further McGrath v. Riddell [2008] UKHL 21.

${ }^{10}$ Cambridge Gas Transportation Corp. v Official Committee of Unsecured Creditors of Navigator Holdings plc and others (above) followed and applied in Rubin v Eurofinance S.A. [2010] EWCA Civ. 895. the company. Proceeds of investments (and of certain loans) were traced to bank accounts held by related companies in the Cayman Islands and the receiver applied to the Grand Court for recognition of its appointment by the Ontario Court and for ancillary orders to enable its recovery of the traced assets. In granting recognition, the Court of Appeal held (among other things) that:

"The Grand Court had jurisdiction (derived from that exercised by the High Court in England) to recognize in the Cayman Islands the receiver as a receiver appointed by a foreign court if it were satisfied that there was a sufficient connection between the defendant company [(or its affiliates in whose names some assets were held)] and the jurisdiction in which the receiver was appointed, to justify recognition of the foreign court's order. Such a connection clearly existed as the defendant companies were obliged to and had submitted to the jurisdiction of the Ontario Court. Since the receiver had the power to litigate on behalf of the defendant companies and the duty to preserve the assets in the interests of all lawful claimants, there was a sufficient connection with the receiver's claim to justify the application for recognition and for authority to identify and recover the defendant companies' assets within the Cayman Islands."

Thus the case is an expression of the Courts' understanding of the principles - later to be given the label of "universality"-with the particular emphasis upon ensuring the success of the "collective" approach to the administration of the debtor's estate.

The Court of Appeal also noted-though not as a condition of the recognition given the receiver in the casethat a relevant consideration could be whether or not the courts of the jurisdiction where the company in receivership was incorporated would themselves recognize a foreign-appointed receiver. In the case of the courts of Ontario, that was noted to be so.

The Al-Sabah Case: In circumstances of personal bankruptcy, the need for cross-border co-operation can be just as urgent and important for the protection of creditors, as in circumstances of corporate insolvency.

In 2004, the worldwide quest of the Kuwaiti Government to recover the proceeds of Sheikh Fahad Al Sabah's massive fraud found support in the Cayman Courts, as ultimately confirmed in a judgment of the Privy Coun$\mathrm{cil}^{11}$. A bankruptcy order against Sheikh Fahad was obtained in the Bahamas, where he lived, by reliance on an unpaid English judgment in favour of the Kuwaiti Government in the order of some L600 million.

The Trustee-in-bankruptcy then applied to the Cayman

\footnotetext{
${ }^{11}$ First instance judgment reported at 2002 CILR 148 upheld in In the Matter of Al Sabah 2004-05 CILR 373. Injunctive measures for the preservation of assets until the bankruptcy proceedings could be instituted were also made available: sub nom Grupo Torras S.A. v Bank of Butterfield et al. 2000 CILR 441.
} 
courts for recognition and authority to enforce the judgment debt as against certain trusts (one of which was originally governed by Bahamian law but was migrated to the Cayman Islands when the English proceedings against Sheikh Fahad were already imminent). The assets of the trusts were alleged to be amenable on the basis that they had been fraudulently disposed into the trusts by Sheikh Fahad and were so recoverable as assets belonging to his bankrupt estate. The recognition of the Trustee and enforcement of the judgment were opposed by Sheikh Fahad on the basis that the Court lacked jurisdiction. By the rather arcane but essential route of reliance on the old Imperial Bankruptcy Act of 1914-long since repealed by the British Parliament, but the extension of which to the Overseas Territories had never been repealed-the Cayman Courts, in the exercise of their bankruptcy jurisdiction, were regarded as having the jurisdiction to grant recognition of and to enforce the orders of other foreign courts of bankruptcy.

In this case, while the enforcement process may be said to have been engaged at the instance of a single judgment creditor-the Kuwaiti Government-the process by which Sheikh Fahad was forced into bankruptcy was nonetheless of universal and "collective" effect, one in which any creditor, wherever located, could have sought relief.

The principle decided by the Al-Sabah case may also be regarded as addressing the objectives of Article 23 of the UNCITRAL Model Law which provides standing for a foreign representative, on being granted recognition, to take proceedings to rectify illegitimate antecedent transactions. The parallel in the Al Sabah case was the setting aside of the earlier fraudulent dispositions of assets into the trusts.

As to the jurisdiction to recognise and enforce the Bahamian bankruptcy judgment: by dint of judicial construction, the jurisdiction of the Grand Court was construed to be as wide as that conferred by section 426 of the modern Insolvency Act 1986 of the UK, which operated as though the bankruptcy had occurred in the territory receiving the request (here, the Cayman Islands). So construed, the powers vested by the Act of 1914 enabled the Grand Court, in the further exercise of its special statutory powers given in local legislation, to apply those powers in favour of the Bahamian trustee, even though similarly wide powers may not have been granted to him there due to the Bahamian statute's stricter requirements. An important consideration in recognising the appointment of the Bahamian Court was the bankrupt's connection to the Bahamas as the requesting state, which there was no reason to doubt, having regard to his established permanent residence there. The bankruptcy judgment having been recognised, there was no need for the sepa- rate recognition or enforcement of the English judgment as that judgment debt, along with all other liabilities and assets of the bankrupt, had been subsumed within his bankruptcy estate.

Accordingly, the assets of the Cayman trusts (USD 30 - 40 million in value) were made available ultimately to the Trustee as part of the global recovery of all the bankrupt's assets in satisfaction of the judgment debt.

The BCCI case: An unheralded success of the Bank of Credit and Commerce (Overseas) Ltd. (BCCI) case has been the unprecedented level of transnational co-operation attained as between the three primary insolvency regimes of BCCI and other international entities and institutions, ever since the worldwide operations of the bank were put into co-ordinated liquidation in 1991. This has been achieved notwithstanding many obstacles encountered at national levels, including the ring-fencing of twenty-seven branches of BCCI by their respective national regulatory authorities, seeking to prefer the interests of local depositors over those of the general worldwide body of creditors of the bank.

Such obstacles notwithstanding, by the crucial agreement reached by which all assets and liabilities were pooled and by the steadfast adherence to the pari passu principle, the Liquidators, acting with the sanction of their supervisory courts (in the Cayman Islands, England and Luxembourg) have managed to achieve practical parity of treatment across the entire BCCI estate. ${ }^{12}$ This parity of treatment has been extended to include even the ring-fenced branches, where returns were realised typically at less than the levels realized by the Liquidators within the pooled estate. Creditors of many of those branches, by a process of "hotchpot" (bringing into account returns paid by the branches) were allowed to "top up" to the levels of dividends paid globally to the creditors. ${ }^{13}$ As the result of the remarkable co-operation between the principal liquidation regimes and the Majority Shareholder that led to the agreed pooling of assets, liabilities and expenses worldwide, the woeful projection of recoveries of a mere few cents in the dollar at the outset have instead now materialised, near the end of the liquidation, into returns of more than 86 cents in the dollar.

Another crucial benefit of early co-operation involved

${ }^{12}$ The sanctioning decision of the English Court is explained in $R e$ BCCI (No. 3) [1993] BCLC 1490. The pooling agreement was approved in the Cayman Islands by Harre J on June 14th 1992: See 1992 CILR Note 7.

${ }^{13}$ Explained in Wight v. Eckhardt Marine GmbH 2003 CILR 211 (at p. 222); and in which the Cayman Liquidators obtained declaratory relief from the Privy Council confirming the applicability of the pari passu principle to ring-fenced branches which remained the legal subsidiaries of BCCI Overseas and provided the indebtedness had not been fully and legally extinguished at the branch level. See also In Re_BCCI 2009 CILR 373: the need for a standard rate of exchange for payment of dividends across global liquidation estates to ensure application of the pari passu principle. 
persuading the United States authorities to abate the very draconian penal sanctions they had imposed on BCCI for its role in the unlawful acquisition of certain American banking interests, a role that led to the subsequent collapse of the banks involved. As a result, after arduous negotiations between the Liquidators (approved by their respective courts) and the American authorities, a plea agreement was struck which allowed, among other things, for the restoration to the BCCI liquidation estate of more than 1.2 billion dollars of forfeited assets. The following is an extract from the BCCI (Overseas) Liquidators' report:

"In November and December of 1991, under the supervision of the Grand Court of the Cayman Islands, the District Court of Luxembourg, and the High Court in England, the BCCI liquidators negotiated an historic plea and co-operation agreement with the United States. The Agreement was presented to the Grand Court of the Cayman Islands and approved in December 1991.”

"In accepting this agreement, Judge Joyce Hens Green of the United States District Court for the District of Columbia stated:

The Plea Agreement now before the court reflects on a truly global measure extraordinary efforts and amazing co-operation of a multitude of signatories representing myriad jurisdictions, to fully settle actions against the corporate defendants, which had operated in 69 countries around the globe, and through the plea restitution, to locate and protect all realizable assets of BCCI for the ultimate benefit of the depositors, creditors, United States financial institutions, and other victims of BCCI. The promise of the Plea Agreement is that those extraordinary efforts, that amazing co-operation, should continue."

Seven and a half years later, as she closed the case, Judge Green found that the promise of the Plea Agreement for unprecedented international co-operation had been realized. She called the agreement a "partnership between the Department of Justice and the Court Appointed Fiduciaries" and praised the foresight of the official liquidators acting pursuant to the direction of the Cayman Court, stating that "their efforts on behalf of the victims in this case and beyond have been truly inspirational". ${ }^{14}$

Here, too, were to be found early emanations of the doctrine of universalism, as the judge reflected that the hallmarks of the Plea Agreement "are principles which should serve to guide the relationship between (countries) in dealing co-operatively with international frauds in the future. Those principles are restitution to victims, cooperation in sharing investigative materials and respect and comity for their respective legal systems". ${ }^{15}$

\footnotetext{
$\overline{{ }^{14} \text { United States v BCCI Holdings (Luxembourg) S.A. } 1999 \text { WL } 499134}$ at 27.
}

The Case of FU JI Food and Catering Services Holdings Limited: From the Cayman Islands perspective, the inventiveness of the common law and the benefit of co-operation have become manifest in this still further example of judicial cooperation in aid of trans-border insolvencies.

The Matter of FU JI Food and Catering Services Holdings Limited (FSD Cause No: 222 of 2010, Grand Court of the Cayman Islands) involved an unusual request for judicial assistance from the High Court of Hong Kong to the Grand Court.

Fu Ji Food and Catering Services, is a Cayman Islands holding company which has subsidiaries operating a substantial business in the People's Republic of China (PRC). The group's underlying business interests-principally in food production, restaurants and related services-experienced massive strain in 2009 and the trading of the company's shares on the Hong Kong Stock Exchange (HKSE) was suspended.

As the company was also registered in Hong Kong, the High Court there was persuaded to place it into provisional liquidation to allow for its capital restructuring, an eminently attainable objective, given the substantial underlying value of the company and the then active interest of potential buyers.

This objective would not have been realised, however, if, despite its provisional liquidation in Hong Kong, creditors remained able to petition for the winding up of the company in the Cayman Islands, the place of its incorporation and domicile, or remained able otherwise to sue the company for recovery of indebtedness before the Cayman Courts.

The company therefore needed the protection of a stay of proceedings by the Cayman Courts and the ability of its provisional liquidators (the JPLs) to act for the company in the Cayman Islands. Hence the request from the High Court of Hong Kong.

The Grand Court first noted the existence of its inherent jurisdiction at common law to send or receive letters of request for judicial assistance. ${ }^{16}$

\footnotetext{
${ }^{15}$ Ibid.

${ }^{16}$ Fully discussed in In the Matter of Basis Yield Alpha Fund (Master) 2008 CILR 50 in which the Grand Court issued letters of request to the Australian court in New South Wales seeking the recognition of its court-appointed liquidators and authority for them to garner information about the Fund in Australia by reliance on the powers of the Australian Court. That court granted the letter of request and accorded the Cayman Proceedings "Foreign main proceedings" recognition in keeping with Article 20 of the UNCITRAL Model law. In Basis Yield Alpha in the Cayman Court, the earliest exercise of the jurisdiction by the Grand Court in which letters of request were sent to the English High Court was noted and applied: In Re BCCI (Overseas), Grand Court Cause 284 of 1991, December 7 2002, unreported, applied. The English Courts judgment in which that request was granted by reliance on the statutory jurisdiction under section 426 of the English Insolvency Act 1986 is reported at Bank of Credit and Commerce Int'l S.A. (1994) 3 All. E.R. 764 (per Rattee J).
} 
Recognising and accepting that the objectives of the restructuring involved the protection of the interests of all the creditors of the company and its subsidiaries, as well as the interests of the company itself (in being allowed to resume listing and trading on the HKSE and so to be divested as a going concern), the request of the High Court was regarded as justified. In granting the request, the Grand Court accepted that, although it was asked to act in aid of the provisional liquidation order of a foreign court over a Cayman Islands company, doing so in the circumstances presented no public policy objections but complied with the need to ensure the protection of the legitimate interests of all stakeholders in keeping with the principle of universality. The following further dicta from Cambridge Gas was noted and applied:

"The purpose of recognition is to enable the foreign office holder or the creditors to avoid having to start parallel insolvency proceedings and to give them the remedies to which they would have been entitled if the equivalent proceedings had taken place in the domestic forum (para 22, page 518)."

In accepting the request, the Grand Court also accepted that the company (Fu Ji Food Ltd) had a real and substantial connection to Hong Kong, being the jurisdiction from which its underlying business interests in the PRC were administered and in which its financing and working capital were raised. The restructuring was aimed at restoring the company to the HKSE and, with the new investor, to enable it to carry on its business in Hong Kong, where the provisional liquidation would close without a winding up.

It was ordered that the JPLs and their Appointment Order be recognized in all respects as if appointed and made by the Grand Court, including, in particular, the power and authority of the JPLs to alter or otherwise deal with the capital structure of Fu Ji Food in accordance with the terms of the Appointment Order. ${ }^{17}$

It was further ordered, therefore, that section 97 of the Cayman Islands Companies Law shall apply in relation to the company so that no action or proceeding shall be commenced or proceeded with against the company within the jurisdiction of the Grand Court except by leave of that court and subject to such terms as it may impose. It was additionally ordered that the JPLs have liberty to apply to the Grand Court in respect of any matter concerning the company and arising during the

\footnotetext{
${ }^{17}$ In this way observing nonetheless, the dictum from Lord Hoffman in Cambridge Gas (518 e - f) as to the limits of the common law jurisdiction to grant recognition and assistance: “At common law, their Lordships think it is doubtful whether assistance could take the form of applying provisions of the foreign insolvency law which form no part of the domestic system. But the domestic court must at least be able to provide assistance by doing whatever it could have done in the case of a domestic insolvency".
}

period of the JLPs' appointment. ${ }^{18}$

Difficulties in deciding whether to accede to foreign insolvency proceedings may, however, arise when there are compelling reasons for winding up in the Cayman Islands or where there are already insolvency proceedings underway before the Cayman Courts involving the same company or involving related companies. These difficulties are likely to be addressed on the case-by-case basis, although the emergent principles of private international law, as recognised in Article 29 of the UNCITRAL Model Law, would maintain the pre-eminence of local insolvency proceedings over foreign proceedings.

In the now commonplace context of the master/feeder hedge fund structure, corporate operations take place in different jurisdictions. Often, in the Cayman context, the structure involves investors' participating in the fund through Cayman Islands entities which are either the feeder or master fund administered in the Cayman Islands, but where the investment management takes place elsewhere in an onshore jurisdiction.

Lancelot Investment Fund Limited: This scenario also applied to Lancelot Investment Fund Limited, a Cayman Islands domiciled open-ended investment fund through which investors provided funds, of over USD1 billion, for investment in specified United States securities to be managed by a United States investment manager.

When allegations of fraudulent misappropriation of its assets were raised by the investment manager against a borrowing syndicate to which all the assets had been loaned, a Trustee-in-Bankruptcy was appointed by the U.S. Court under Chapter 7 of the US Bankruptcy Code and he took control of the known assets, all of which were located in the United States.

Nonetheless, some investors-a major international bank and a third party investment fund, to the combined value of more than USD80 million-petitioned the Cayman Court for the winding up of Lancelot in the Cayman Islands. They petitioned on the basis that they had made their investments through Lancelot as a Cayman Islands entity governed by Cayman Islands law and, as the substratum had failed amidst the allegations of fraud, they were entitled to a winding up on the "just and equitable basis", so that their interests may be protected by the involvement of a liquidator acting under the aegis of the Cayman Court. A particular concern was that it was the

\footnotetext{
${ }^{18}$ Unusual though the case was, it was not unprecedented. Kawaley J. of the Bermuda High Court In Re Dickson Group Holdings Limited [2008] Bda LR 34, granted a stay of proceedings against a Bermuda company, at the instance of its Hong Kong Court appointed permanent liquidators, to enable and facilitate parallel schemes of arrangement under both Bermudian and Hong Kong law designed to restructure the company's debt and capital so that its shares (under substantially new ownership) could once again trade on the HKSE.
} 
investment manager responsible for placing the loans with the syndicate, which had itself petitioned the U.S Court after the allegations of fraud had come to light.

In an approach that demonstrates that there can indeed be a "(modified) universalism", Quin J. of the Grand Court made the order for winding up over the objection (raised by letter but without formal appearance) of the Chapter 7 Trustee and the majority of investors (who formally appeared), as he was satisfied that the petitioners should have someone to represent their particular concerns to both the U.S. Court and the Cayman Court. Even though the judge recognized the United States as the principal place for the liquidation of Lancelot, as its incorporation and many of the arrangements for the investments were governed by Cayman Islands law and would therefore have to be examined and assessed against that law, he resolved to appoint only a single liquidator, mindful that the Chapter 7 Trustee may wish and should be free to apply for the recognition of his appointment in the Cayman Islands. Furthermore, the Cayman winding up order was stayed, in keeping with the principles of comity and universality in corporate insolvency.

This approach would give both the Cayman Liquidator and the Chapter 7 Trustee an opportunity to discuss their respective roles and attempt to reach an agreed protocol for the efficient liquidation of Lancelot, thus avoiding multiple proceedings and duplication of costs. Further, the Court was keen to encourage co-operation with the US Court, both in recognizing the Cayman Liquidator in the US Court, with the Chapter 7 Trustee reconsidering his stated intention to oppose, and in the Trustee similarly being encouraged to apply to the Cayman Court for recognition of his appointment.

The wisdom and efficacy of this approach has been borne out by the fact that a protocol was entered into between the two Court-appointed office holders and has been successfully implemented. In practice, the minimal costs - of having a Cayman liquidator who can liaise with his U.S. counter-part and the U.S Court and report to the Cayman Court, with an eye to the Cayman public interests in the proper investigation and resolution of allegations of fraud for the protection of investors in a Cayman Fund company and for the protection of investors as a whole - is likely to prove a small price to pay. While the protocol allows in practical terms for the imperative that insolvency shall be "both unitary and universal" - (as Lord Hoffmann further described the principle in the House of Lords decision in Re HIH Casualty \& Gen. Ins. Ltd (above) p. 852, para 6) -it also allows for the legitimate public policy concerns recognized by the Grand Court. In this regard, the following passage from Lord Hoffmann in the $\mathrm{HIH}$ case (at para 30) was adopted and applied:

"The primary rule of private international law which seems to me applicable to this case is the principle of (modified) universalism, which has been the golden thread running through English cross-border insolvency law since the 18th century. That principle requires that English courts should, so far as is consistent with justice and UK public policy, co-operate with the courts in the country of the principal liquidation to ensure that all the company's assets are distributed to its creditors under a single system of distribution. That is the purpose of the power to direct remittal [of assets to Australia] ${ }^{19}$ (emphasis supplied)."

In citing and following the earlier decision of Henderson $\mathrm{J}$ of the Grand Court in Re Philadelphia ${ }^{20}$ Quin $\mathrm{J}$ also applied the following dictum from Robert Walker J. (as he then was) in Re Gordon \& Breach Science Publishers (1995) 2 BCLC at 199: dictum that had found favour with Henderson J. in Re Philadelphia.

"Fairness and commercial morality may require that a substantial independent creditor (in this case investor) which feels itself to be prejudiced by what it regards as sharp practice should be able to insist on the company's affairs being scrutinized by the process which follows a compulsory order. Such a creditor is entitled to an investigation which is not only independent, but can be seen to be independent. This may be so even where the voluntary liquidation is already well advanced and a compulsory order may cause further expense and delay...."

Such concerns, about "fairness and commercial morality”, have dictated the need in still further cases for the appointment of different liquidators after winding up had commenced by removing liquidators who had been appointed but who were likely to suffer from a potential conflict of interest. See Re Bear Sterns High-Grade Structural Credit Enhanced Leverage (Overseas) Ltd. Grand Court, February 22, 2008, unreported.

Potential conflicts of interests to arise from the appointment of the same liquidators over both the master and feeder funds have also dictated the need for separate appointments and separate windings up before different Courts: In the Matter of DD Growth Premium Master Fund 2009 CILR Note 11.

The foregoing survey of cases reveal the approach taken by the Cayman Courts at common law and the general adherence, where circumstances and policy allow, towards the unitary and collective approach to trans-

\footnotetext{
${ }^{19}$ In the Matter of Lancelot Investment Fund Limited 2009 CILR 7.

${ }^{20}$ In re Philadelphia Alternative Asset Fund Ltd. 2006 CILR, Note 7, unreported.
} 
border co-operation in insolvency matters. $^{21}$

\section{Cayman Islands Legislation Complies with UNCITRAL Model}

Legislation, aimed at expressing statutory confirmation of the common law precepts of co-operation in transborder proceedings and at further achieving the objectives of the UNCITRAL Model Law on Cross-Border Insolvency, was passed in 2009 with the enactment of Part XVII of the Companies Law. This came about although the Cayman Islands, unlike the United Kingdom, have not itself subscribed to the UNCITRAL Model Law.

\section{Orders Made Under Cayman Islands Legislation}

Pursuant to Part XVII, orders "ancillary to foreign bankruptcy proceedings," have already been made by the Grand Court.

Among these, on 24th June 2009, the Icelandic courtappointed "Moratorium Assistant" in bankruptcy proceedings in relation to the affairs of Straumur BankIceland's largest investment bank-was recognized by the Grand Court as, in the words of the Law, "a foreign representative”. This recognition authorized him to act within the Cayman Islands on behalf of Straumur Bank, including for the purposes of identifying and restraining assets of the Bank located within the Cayman Islands. Out of concern that competing claims to those assets may be brought against the Bank in the Cayman Islands, on the 9th September 2010 a further order was made on the application of the Moratorium Assistant enjoining any application against the Bank in the Cayman Islands without the leave of the Court. The Court was informed about the nature of the Icelandic bankruptcy proceedings (which afforded the Bank a moratorium during which it

\footnotetext{
${ }^{21}$ Despite this history, Cayman insolvency proceedings have sometimes not gained ready recognition by the U.S. Bankruptcy Court for reasons which seem to ascribe too narrow an ambit to the fact of incorporation in the Cayman Island and to the level of corporate activity that takes place there. For instance, notwithstanding that the SphinX Funds were being liquidated in the Cayman Islands as the place of incorporation and without any challenge as to it being the proper forum, recognition of the Cayman proceedings were only accorded the "foreign non-main proceeding status:” Re SphinX Ltd 371 B.R.10 (Bankr. S.D.N.Y. July 2007). Cayman proceedings were refused recognition altogether on a very narrow view being taken of the test whether the Fund had an "establishment" in Cayman and again, notwithstanding the presumption accorded the place of incorporation as the proper forum and the fact that liquidation was underway in the Cayman Islands: In re Bear Sterns Master Fund 374 B.R. 122 (Bankr. SDNY Sept. 2007). A more acceptable position has however been taken in comparable circumstances by the same judge (Lifland J.) on July 22, 2010, by recognition as "foreign main proceedings", the liquidation in the BVI of Fairfield Sentry Limited: In re Fairfield Sentry Limited, et al. Case No. 1013164 S.N.D.Y. 22 July 2010).
}

sought to arrive at a composition with all its creditors) and was satisfied that the objectives of the Icelandic Court should be supported. In enjoining the commencement of proceedings in the Cayman Islands, the Court stated:

"Notwithstanding that there are currently no proceedings against Straumur in the Cayman Islands and there are no known Cayman Islands creditors, the fact that there are significant Cayman assets may be sufficient to tempt a putative creditor of Straumur to commence proceedings here. In order to protect the global integrity of the Composition, it is of crucial importance that creditors of Straumur (wherever they may be located) should not be permitted, while the moratorium is in place, to issue proceedings in the Cayman Islands against Straumur." 22

The local statutory jurisdiction was also invoked on February 5th 2010. Then Jones J. of the Grand Court granted the petition of Irving H. Picard in his capacity as Trustee of Bernard L. Madoff Investment Securities LLC (BLMIS), for a declaration that he has the right to act in the Cayman Islands on behalf of BLMIS. BLMIS was incorporated in accordance with the laws of the State of New York and was then the subject of bankruptcy proceedings before the Hon. Burton Lifland in the U.S. Bankruptcy Court for the Southern District of New York. On 15th December 2008, Mr. Picard had been appointed trustee for the liquidation of the business of BLMIS with all the duties and powers of a trustee as prescribed in the U.S. Securities Investor Protection Act, 1970.

The Grand Court pronounced its decision in these terms: ${ }^{23}$

"Part XVI of the Companies Law (2009 Revision) was enacted in 2008 and came into force with effect from 1st March 2009. Section 241(1) (a) did not change the prexisting conflict of laws rules relating to this subject. Its purpose is to provide foreign representatives with a convenient and expeditious manner of establishing their credentials and right to act on behalf of the debtor in a way which will have universal effect within the jurisdiction, without the need to establish his right separately as against every individual counterparty. The Cayman Islands conflict of laws rules applicable to this issue are well established. First, all matters concerning the constitution of a corporation are governed by the place of its incorporation. It follows that the law of the place of incorporation determines who are the company's officials authorised to act on its behalf. Second, the authority of a

\footnotetext{
${ }^{22}$ Cause No. FSD 0188/2010-ASCJ-In the Matter of Straumur-Burdaras Investment Bank HF, written judgment delivered on 9th September 2010.

${ }^{23}$ Cause FSD 47 OF 2010, written judgment delivered on 5th February 2010: In the Matter of BLMIS (In Securities Investor Protection Act Liquidation).
} 
bankruptcy trustee or liquidator appointed under the law of the place of a company's incorporation is recognised in the Cayman Islands (Dicey and Morris, The Conflict of Laws 10th Ed., Rule 139(2) and Rule 143).”

"...as a matter of Cayman Islands law, Mr. Picard is entitled to be recognised as the sole person having the right to act on behalf of BLMIS in this jurisdiction."

\section{Strong Tradition of Cooperation Set to Continue}

In the light of such decisions emanating from the early exercise of the statutory jurisdiction under Part XVII of the Companies Law, there is every reason to believe that the strong tradition of co-operation in trans-national insolvency and bankruptcy matters at common law will continue by the Cayman Islands Courts.

Considerations such as whether the foreign court presides at the "centre of main interests" of the debtor entity or whether the foreign proceedings are "main" or "nonmain proceedings" or whether in that regard the debtor entity had an "establishment" in the foreign jurisdiction -all matters of import under the UNCITRAL Model Law $^{24}$ — can all be accorded due if not exclusive weight by the Cayman Courts in deciding whether or not to grant recognition to foreign proceedings and foreign representatives. This ability to co-operate can, in large measure, be attributed to the flexibility provided by the wide discretion vested in the Court in exercise of the jurisdiction under Cayman Islands law.

Accordingly, the Cayman Islands jurisprudence can be expected to develop well in pace with the development of the common law principles of comity, in keeping with the principles of the UNCITRAL Model Law and in keeping with the legitimate demands of the international financial markets within the wider global economy.

\footnotetext{
${ }^{24}$ Cause As well as under U.K. Law by virtue of Insolvency Regulations 2006 giving affect to the UNCITRAL Model Law; also in United States Law under Chapter 15 of the U.S. Bankruptcy Code which also gives effect to the UNCITRAL Model Law. The U.K. and the U.S. are two of the 20 States now adhering to the Model Law. Similar considerations will arise as a matter of E.U. Law by virtue of E.C. Regulations No. 1346/2000 (29th May 2000) on Insolvency Proceedings and the European Union Convention on Insolvency Proceedings.
} 